\title{
Numerical Modelling Analysis for Carrier Concentration Level Optimization of CdTe Heterojunction Thin Film-Based Solar Cell with Different Non-Toxic Metal Chalcogenide Buffer Layers Replacements: Using SCAPS-1D Software
}

\author{
Samer H. Zyoud ${ }^{1,2,3, *(D)}$, Ahed H. Zyoud ${ }^{4}$, Naser M. Ahmed ${ }^{3}$ and Atef F. I. Abdelkader ${ }^{1,2}(\mathbb{D})$ \\ 1 Department of Mathematics and Science, Ajman University, Ajman P.O. Box 346, United Arab Emirates; \\ a.abdelkader@ajman.ac.ae \\ 2 Nonlinear Dynamics Research Center (NDRC), Ajman University, Ajman P.O. Box 346, United Arab Emirates \\ 3 School of Physics, Universiti Sains Malaysia, Penang 11800, Malaysia; naser@usm.my \\ 4 Department of Chemistry, An-Najah National University, Nablus, Palestine; ahedzyoud@najah.edu \\ * Correspondence: s.zyoud@ajman.ac.ae
}

check for updates

Citation: Zyoud, S.H.; Zyoud, A.H.; Ahmed, N.M.; Abdelkader, A.F.I. Numerical Modelling Analysis for Carrier Concentration Level Optimization of CdTe Heterojunction Thin Film-Based Solar Cell with Different Non-Toxic Metal Chalcogenide Buffer Layers Replacements: Using SCAPS-1D Software. Crystals 2021, 11, 1454. https://doi.org/10.3390/cryst11121454

Academic Editor: Saripally Sudhaker Reddy

Received: 21 October 2021

Accepted: 19 November 2021

Published: 25 November 2021

Publisher's Note: MDPI stays neutral with regard to jurisdictional claims in published maps and institutional affiliations.

Copyright: (c) 2021 by the authors. Licensee MDPI, Basel, Switzerland. This article is an open access article distributed under the terms and conditions of the Creative Commons Attribution (CC BY) license (https:/ / creativecommons.org/licenses/by/ $4.0 /)$.

\begin{abstract}
Cadmium telluride (CdTe), a metallic dichalcogenide material, was utilized as an absorber layer for thin film-based solar cells with appropriate configurations and the SCAPS-1D structures program was used to evaluate the results. In both known and developing thin film photovoltaic systems, a CdS thin-film buffer layer is frequently employed as a traditional $n$-type heterojunction partner. In this study, numerical simulation was used to determine a suitable non-toxic material for the buffer layer that can be used instead of CdS, among various types of buffer layers (ZnSe, $\mathrm{ZnO}, \mathrm{ZnS}$ and $\left.\mathrm{In}_{2} \mathrm{~S}_{3}\right)$ and carrier concentrations for the absorber layer $\left(N_{\mathrm{A}}\right)$ and buffer layer $\left(N_{\mathrm{D}}\right)$ were varied to determine the optimal simulation parameters. Carrier concentrations $\left(N_{\mathrm{A}}\right.$ from $2 \times 10^{12} \mathrm{~cm}^{-3}$ to $2 \times 10^{17} \mathrm{~cm}^{-3}$ and $N_{\mathrm{D}}$ from $1 \times 10^{16} \mathrm{~cm}^{-3}$ to $1 \times 10^{22} \mathrm{~cm}^{-3}$ ) differed. The results showed that the use of CdS as a buffer-layer-based CdTe absorber layer for solar cell had the highest efficiency (\%) of $17.43 \%$. Furthermore, high conversion efficiencies of $17.42 \%$ and $16.27 \%$ were for the $\mathrm{ZnSe}$ and $\mathrm{ZnO}$-based buffer layers, respectively. As a result, $\mathrm{ZnO}$ and $\mathrm{ZnSe}$ are potential candidates for replacing the CdS buffer layer in thin-film solar cells. Here, the absorber (CdTe) and buffer (ZnSe) layers were chosen to improve the efficiency by finding the optimal density of the carrier concentration (acceptor and donor). The simulation findings above provide helpful recommendations for fabricating high-efficiency metal oxide-based solar cells in the lab.
\end{abstract}

Keywords: absorber layer and buffer layer; CdTe; ZnSe; conversion efficiency; SCAPS-1D; solar cell

\section{Introduction}

The challenge of global warming has prompted the further study of solar and other renewable energy sources. Solar cells are a fundamental component of solar energy. Different materials are used to create solar cells, with silicon being the most commercially feasible and prevalent. The majority of the alternative materials were developed with the goal of producing low-cost, high-efficiency and long-lasting solar cells. Although the efficiency is still modest, nanostructured metal oxide solar cells have moved a step farther in delivering clean, cheap and sustainable solar cells [1]. Solar energy conversion to useable power using a solid-state $p-n$ junction based photovoltaic (PV) device offers enormous promise in the efforts to reduce our current reliance on fossil fuels and, as a result, to reduce harmful greenhouse gas emissions [2,3].

Due to its unique properties, cadmium telluride (CdTe) thin film is widely employed in a variety of optical and electrical applications. CdTe thin-film cells are gaining popularity because of their abundance, excellent efficiency, long-term stability and low cost of manufacture [4] and they can be used in a variety of devices such as nanodevices, sensors 
and solar cells [5]. CdTe is classified as an II-VI transition metallic dichalcogenide and has a high absorption coefficient $\left(>10^{5} \mathrm{~cm}^{-1}\right)$ that is greater than other known semiconductor materials with a narrow band gap $(\mathrm{Eg} \sim 1.5 \mathrm{eV})[6,7]$. This band gap value is suitable for the visible solar light spectrum [8-10].

Thin-film solar cell applications make extensive use of metal chalcogenide semiconductors such as cadmium telluride (CdTe). This is due to its inexpensive cost, abundance on the planet and reasonable conversion efficiency. Because of its excellent performance, outdoor long-term stability, strong optical absorption, low cost, adjustable bandgap and unique optoelectronic features, CdTe was chosen as the absorber layer in this work. Various attempts have been made on CdTe to improve its stability and conversion efficiency [11]. In the form of $p$-type semiconductors, CdTe is a potential absorbing material for thin-film PV technology [12]. Despite the widespread usage of CdTe thin films, its primary form has a low conversion efficiency in PEC procedures. When electrodeposited on Ni substrates, CdTe thin films have poor conversion efficiency, depending on the redox couplings and the type of conduction utilized [13]. PEC performance was also poor when CdTe thin films were formed on FTO and ITO substrates [14,15]. When CdTe films were deposited by spray pyrolysis [16], the conversion efficiency was $3.4 \%$, whereas chemical bath-formed films that had been treated with $\mathrm{CdCl}_{2}$ had a conversion efficiency of 2.5\% [17-19]. CdTe thin films have been reported to have a conversion efficiency of $17.5 \%$ or more under certain circumstances [9]. To increase low PEC performance, CdTe thin films are frequently combined with other systems, such as CdS films [14,20]. Cadmium sulfide (CdS) is a well-known II-VI compound semiconductor with excellent transparency, a straight band gap transition (Eg $2.4 \mathrm{eV})$, strong electron affinity $(\sim 4.2 \mathrm{eV})$ and $n$-type conductivity [21,22]. CdS also enhances the interface fit of lattice heterojunctions, increases the surplus carrier lifetime and optimizes the band alignment of the devices in which it is utilized [23]. The optical, electrical and structural properties of CdS films are useful in a wide variety of scientific, technical and commercial applications involving optoelectronic devices, particularly solar cells [24]. CdS is a promising option for use as a buffer layer in CdTe thin film-based solar cells due to its properties of low surface recombination and little absorption loss. On the other hand, CdS can be hazardous to the environment and human health due to its high toxicity. Different materials with a larger band gap as well as non-toxic compounds such as $\mathrm{ZnS}(\mathrm{O}, \mathrm{OH})$ and $\mathrm{ZnS}$ have been studied as suitable buffer layers for thin-film solar cells [25-27]. However, because of the complex reaction mechanism and light soaking effects of these buffer layers, cell durability and repeatability may be compromised [28].

$\mathrm{CdS} / \mathrm{CdTe}$ thin films produced on ITO substrates have been shown to have a conversion efficiency of $3.5 \%$ and when silver (Ag) was coated on the films, the conversion efficiency increased to $9.82 \%$ [29]. In multi-junction CdTe/CdS combinations, conversion efficiencies of up to $13 \%$ have also been recorded [30]. Multi-junction CdS/CdTe/ZnTe/ZnTe:Cu cells have a high conversion efficiency of $13.38 \%$ [31,32]. The efficiency of the $\mathrm{CdS} / \mathrm{CdTe}: \mathrm{Cu} / \mathrm{CNT}$ structure has been reported to be up to $14.1 \%$ [33]. The buffer layer connects the absorber and window layers and it is important for a variety of reasons, including providing structural stability for the thin film and preventing static electricity in the absorber layer $[34,35]$.

In heterojunction thin-film solar cells, the buffer layer generally serves as a focus point. The photons that reach the absorption layer through the reach-in layer travel via the buffer layer. As a result, the number of photons that is lost due to absorption in the buffer layer should be kept to a minimum. As a result, in the buffer layer, electrical resistance and minimal surface recombination are required. In order to provide the buffer layer between the absorber layer and the transparent window layer, it is necessary to provide thin-film solar cell stability. As a result, the buffer layer must have a large energy gap. This permits the majority of visible light to pass through to the absorption layer. On the other hand, for the depletion layer to overlap, the bandgap margins of the buffer and the absorption layer should be roughly compatible. In heterojunction thin-film solar cells, metal chalcogenides such as CdS, CdSe, ZnS, ZnSe and $\operatorname{In}_{2} \mathrm{~S}_{3}$ are ideal for the role of a buffer layer. CdS, CdSe and CdTe are the most popular metal chalcogenide compounds that are used in thin-film 
solar cells with heterojunctions. These substances are harmful to the environment. Green and less dangerous chemicals (such as $\mathrm{ZnS}, \mathrm{ZnSe}, \mathrm{ZnO}, \mathrm{Zn}_{1-}{ }_{-x} \mathrm{Mg}_{\mathrm{x}} \mathrm{O}$ and $\mathrm{In}_{2} \mathrm{~S}_{3}$ ) should be studied and assessed as a substitute for the traditional hazardous semiconductors that are often used in heterojunction thin-film solar cells [36]. Numerical simulations may be used to investigate the influence of various materials on the final properties of solar cells. The results of such numerical research and analyses can be utilized to improve device performance [35,37-39]. The optimum and best structure of thin film-based solar cells is determined by numerical modeling. There is currently a scarcity of thin-film solar cell simulation research. As a result, we have narrowed the scope of our numerical simulation in this work by utilizing SCAPS-1D software to investigate the material that is needed for the buffer layer and for substituting the CdS with another material. A different buffer layer's effect on cell performance was investigated. Different buffer layer materials (CdS, $\left.\mathrm{ZnO}, \mathrm{ZnSe}, \operatorname{In}_{2} \mathrm{~S}_{3}, \mathrm{ZnS}\right)$ have been shown to exhibit $J-V$ characteristics $\left(V_{\mathrm{oc}}, J_{\mathrm{sc}}, F F\right.$ and $\eta$ ) under standard illumination AM1.5G, $100 \mathrm{~mW} / \mathrm{cm}^{2}, 300 \mathrm{~K}$ (Table 1). The primary goal of this research is to replace CdS with a different buffer material. Furthermore, the concentration densities of carriers (acceptor and donor) have been considered in this study.

Table 1. The working points and illumination.

\begin{tabular}{cccc}
\hline Working Points & Value & Spectrum & AM1.5G Spectrum \\
\hline Temperature $(\mathrm{K})$ & 300 & Wavelength range $(\mathrm{nm})$ & $200-4000$ \\
Bias voltage $(\mathrm{V})$ & 0.00 & Transmission $(\%)$ & 100 \\
Frequency $(\mathrm{Hz})$ & $1 \times 10^{6}$ & Ideal light current $\left(\mathrm{mA} / \mathrm{cm}^{2}\right)$ & 20 \\
Series resistance $\left(\Omega \mathrm{cm}^{2}\right)$ & 0 & Transmission of attenuation filter $(\%)$ & 100 \\
Shunt resistance $\left(\Omega \mathrm{cm}^{2}\right)$ & $1 \times 10^{30}$ & Ideal light current cell $\left(\mathrm{mA} / \mathrm{cm}^{2}\right)$ & 0 \\
\hline
\end{tabular}

\section{Numerical Modeling and Material Parameters}

SCAPS-1D was created at ELIS, University of Ghent and it may be used for free in photovoltaic research investigations $[40,41]$. The SCAPS-1D structure program is frequently used to model the electrical and optical characteristics of AC and DC heterojunctions. It is primarily designed for CIGS and CdTe solar cells. The main goal of SCAPS-1D is to use an existing database to explore the properties of thin film-based solar cells with various buffer layers. SCAPS-1D simulation solutions may be used to examine outputs such as voltage and currents on illumination and dark characteristics. This simulation may also generate a temperature-based analysis. SCAPS-1D simulation may also provide important information such as recombination profiles, the current density of individual carriers as a positional function and electrical physical distribution. The main goal is to replicate solar cells in order to achieve high efficiency before beginning actual experimental manufacturing with various parameters. SCAPS-1D simulation may be used to investigate the impact of various parameters on $\left(V_{\mathrm{OC}}, J_{\mathrm{SC}}, F F, \eta\right)$ and operating temperature.

\subsection{Numerical Modeling}

SCAPS-1D can solve Poisson's equation for holes and electrons (Equation (1)) [42]:

$$
\frac{d^{2} \Psi}{d x^{2}}=\frac{e}{\epsilon_{o} \epsilon_{r}}\left[P(x)-n(x)+N_{D}-N_{A}+\rho_{P}-\rho_{n}\right]
$$

where $\Psi$ is the electrostatic potential, $e$ is the elementary charge, $\epsilon_{r}$ is the relative permittivity and $\varepsilon_{o}$ is the vacuum permittivity, $p$ is hole concentration, $n$ is electron concentration, $N_{D}, N_{A}$ are donor and acceptor charge concentrations, respectively and $\rho_{p}$ and $\rho_{n}$ are holes and electrons distribution, respectively.

Additionally, it can also solve the continuity equation (Equation (2)) [43]:

$$
\frac{d^{2} \Psi}{d x^{2}}=\frac{e}{\epsilon_{o} \epsilon_{r}}\left[P(x)-n(x)+N_{D}-N_{A}+\rho_{P}-\rho_{n}\right]
$$


where $J_{p}$ and $J_{n}$ are the hole and electron current densities, respectively and $R$ and $G$ are recombination rates, respectively.

Carrier transport occurs by drift and diffusion according to Equations (3) and (4), respectively:

$$
\begin{aligned}
& J_{n}=D_{n} \frac{d n}{d x}+\mu_{n} n \frac{d \varphi}{d x} \\
& J_{p}=D_{p} \frac{d p}{d x}+\mu_{p} p \frac{d \varphi}{d x}
\end{aligned}
$$

where $\varphi$ is the potential difference and $D_{n}$ and $D_{p}$ are the electron and hole diffusion constant, respectively. $\mu_{n}$ and $\mu_{p}$ are the electron and hole mobility and $n$ and $p$ are the electron and hole carrier concentration.

\subsection{The Suggested Thin-Film Solar Cell Device Structure}

Figure 1 shows the thin film's structure, which includes a $p$-type absorber $(\mathrm{CdTe})$ layer on a molybdenum (Mo) coated back glass substrate, an $n$-type buffer layer (CdS, $\operatorname{In}_{2} \mathrm{~S}_{3}$, $\mathrm{ZnS}, \mathrm{ZnO}, \mathrm{ZnSe}$ ) and $\mathrm{SnO}_{2}$ window layer.
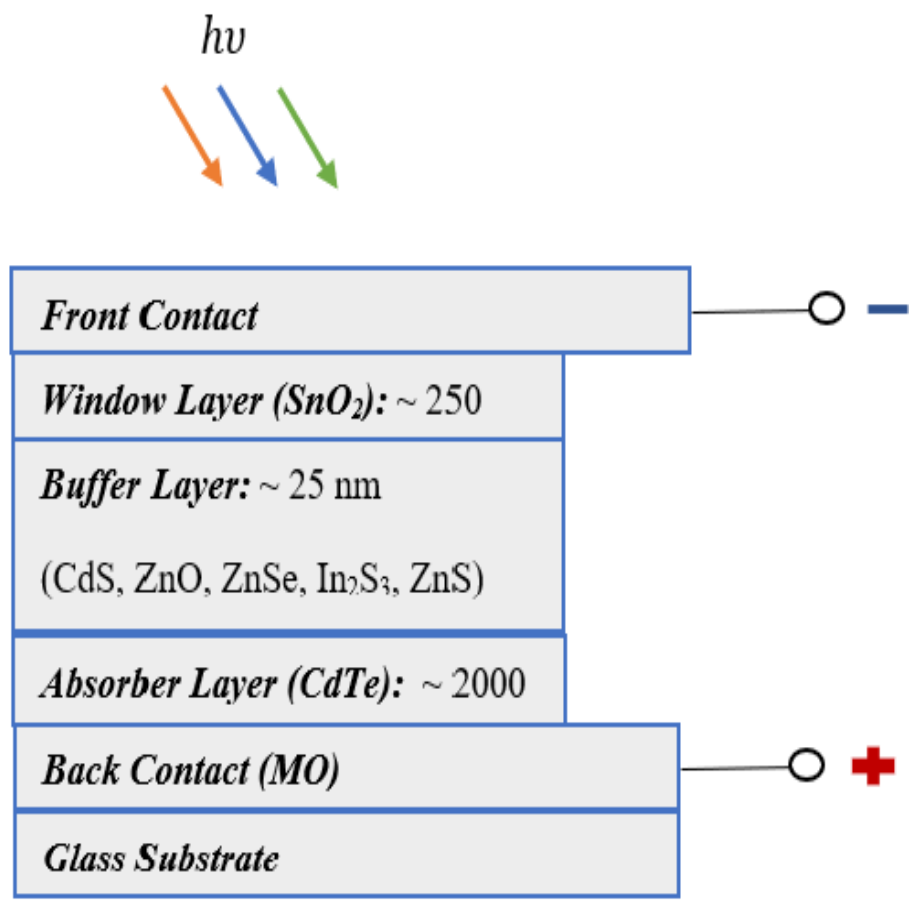

Figure 1. Schematic diagram of thin film.

\subsection{Numerical Material Parameters}

The starting conditions (bias voltage, operating temperature, lighting and so on) should be established, as stated in Table 1, at the start of the simulation. Table 2 shows the reflection and transmission of the front and back contacts, respectively. Each layer's material characteristics should be entered into a software application. Table 3 shows the material parameter characteristics for the thin film layers and lists the physical parameters utilized in the Mo/absorber/buffer/window solar cell simulation [44-61]. 
Table 2. Electrical parameters properties of back and front contact used for the metal oxide SCAPS-1D simulation.

\begin{tabular}{|c|c|c|c|}
\hline \multicolumn{2}{|c|}{ Electrical Properties } & \multirow{2}{*}{$\frac{\text { Back Contact }}{1 \times 10^{7}}$} & \multirow{2}{*}{$\begin{array}{c}\text { Front Contact } \\
1 \times 10^{7}\end{array}$} \\
\hline Thermionic emission surface & Electron & & \\
\hline recombination velocity $(\mathrm{cm} / \mathrm{s})$ & Holes & $1 \times 10^{7}$ & $1 \times 10^{7}$ \\
\hline \multicolumn{2}{|c|}{ Metal work function $(\mathrm{eV})$} & 5 & 4.1 \\
\hline \multirow{2}{*}{ Majority carrier barrier height $(\mathrm{eV})$} & Relative to $E_{\mathrm{F}}$ & 0.4 & 0.1 \\
\hline & Relative to $E_{\mathrm{V}}$ or $E_{\mathrm{C}}$ & -0.1227 & 0.0199 \\
\hline \multirow{2}{*}{ Allow contact tunneling } & Effective mass of electron & 1 & 1 \\
\hline & Effective mass of holes & 1 & 1 \\
\hline \multirow{3}{*}{ Optical Properties } & Filter mode & Reflection & Transmission \\
\hline & Filter value & 0.8 & 0.95 \\
\hline & Complement of filter value & 0.2 & 0.05 \\
\hline
\end{tabular}

Table 3. The electrical parameters for the thin-film solar cell at $300 \mathrm{~K}$.

\begin{tabular}{|c|c|c|c|c|c|c|c|}
\hline Electrical Parameter & $p$-CdTe & $n-\mathrm{CdS}$ & $n-Z n S$ & $n$-ZnSe & $n-\mathrm{ZnO}$ & $n-\operatorname{In}_{2} S_{3}$ & $\mathrm{SnO}_{2}$ \\
\hline Thickness ( $\mu \mathrm{m})$ & 2 & 0.025 & 0.025 & 0.025 & 0.025 & 0.025 & 0.25 \\
\hline Band gap $(\mathrm{eV})$ & 1.5 & 2.4 & 3.5 & 2.9 & 3.3 & 2.8 & 3.6 \\
\hline Electron affinity $(\mathrm{eV})$ & 3.9 & 4.5 & 4.5 & 4.09 & 4.45 & 4.7 & 4 \\
\hline Dielectric permittivity (relative) & 9.4 & 10 & 10 & 10 & 9 & 13.5 & 9 \\
\hline $\mathrm{CB}$ effective density of states $\left(\mathrm{cm}^{-3}\right)$ & $8 \times 10^{17}$ & $1.5 \times 10^{18}$ & $1.5 \times 10^{18}$ & $1.5 \times 10^{18}$ & $2.2 \times 10^{18}$ & $1.8 \times 10^{19}$ & $2.2 \times 10^{18}$ \\
\hline VB effective density of states $\left(\mathrm{cm}^{-3}\right)$ & $1.8 \times 10^{19}$ & $1.8 \times 10^{18}$ & $1.8 \times 10^{18}$ & $1.8 \times 10^{18}$ & $1.8 \times 10^{19}$ & $4 \times 10^{18}$ & $1.8 \times 10^{18}$ \\
\hline Electron thermal velocity $(\mathrm{cm} / \mathrm{s})$ & $1 \times 10^{7}$ & $1 \times 10^{7}$ & $1 \times 10^{7}$ & $1 \times 10^{7}$ & $1 \times 10^{7}$ & $1 \times 10^{7}$ & $1 \times 10^{7}$ \\
\hline Hole thermal velocity $(\mathrm{cm} / \mathrm{s})$ & $1 \times 10^{7}$ & $1 \times 10^{7}$ & $1 \times 10^{7}$ & $1 \times 10^{7}$ & $1 \times 10^{7}$ & $1 \times 10^{7}$ & $1 \times 10^{7}$ \\
\hline Electron mobility $\left(\mathrm{cm}^{2} / \mathrm{V} \mathrm{s}\right)$ & 300 & 50 & 50 & 50 & 100 & 400 & 100 \\
\hline Hole mobility $\left(\mathrm{cm}^{2} / \mathrm{V} \mathrm{s}\right)$ & 40 & 20 & 20 & 20 & 25 & 210 & 25 \\
\hline $\begin{array}{l}\text { Shallow uniform donor density } \\
\qquad N_{\mathrm{D}}\left(\mathrm{cm}^{-3}\right)\end{array}$ & 0 & $1 \times 10^{22}$ & $1 \times 10^{22}$ & $1 \times 10^{22}$ & $1 \times 10^{22}$ & $1 \times 10^{22}$ & $1 \times 10^{22}$ \\
\hline $\begin{array}{l}\text { Shallow uniform acceptor density } \\
\qquad N_{\mathrm{A}}\left(\mathrm{cm}^{-3}\right)\end{array}$ & $2 \times 10^{15}$ & 0 & 0 & 0 & 0 & 0 & 0 \\
\hline
\end{tabular}

\section{Results and Discussion}

\subsection{Effect of Different Buffer Layer on Thin Film-Based Solar Cell}

Cadmium (Cd) is poisonous and CdS is classified as a carcinogen, both of which are harmful to the environment and humans. Other potential buffer layers, such as $\mathrm{ZnO}, \operatorname{In}_{2} \mathrm{~S}_{3}$, $\mathrm{ZnSe}$ and $\mathrm{ZnS}$, have been explored as a result. The optimal photovoltaic parameters $\left(V_{O C}\right.$ $J_{S C}, F F$ and $\eta \%$ ) of a CdTe thin film with various buffer layers are shown in Table 4 and Figure 2. It should be highlighted that CdS performs the best as a buffer layer, obtaining an efficiency of $17.43 \%$. The results also reveal that buffer layers made of $\mathrm{ZnSe}$ and $\mathrm{ZnO}$ have excellent efficiency, at $17.42 \%$ and $16.27 \%$, respectively. While buffer layers based on $\mathrm{ZnS}$ and $\mathrm{In}_{2} \mathrm{~S}_{3}$ had a lower efficiency of $15.88 \%$ and $14.23 \%$, respectively. As a result, $\mathrm{ZnO}$ and $\mathrm{ZnSe}$ have been proposed as replacements for CdS as a buffer layer in thin films [62].

Figure 3 a depicts the $J-V$ characteristics for various buffer layers. It is worth noting that when the efficiency is high, the curve shifts to the right.

Table 4. Effectiveness of the buffer material (donor) on $J-V$ characteristics.

\begin{tabular}{ccccc}
\hline Buffer Layer & $\boldsymbol{V}_{\text {OC }}(\boldsymbol{V})$ & $J_{\text {SC }}\left(\mathbf{m A} / \mathbf{c m}^{\mathbf{2}}\right)$ & $\boldsymbol{F F}$ & Efficiency (\%) \\
\hline $\mathrm{CdS}$ & 0.9113 & 23.4497335 & 81.41 & 17.43 \\
$\mathrm{ZnSe}$ & 0.9112 & 23.484037 & 82.38 & 17.42 \\
$\mathrm{ZnO}$ & 0.9142 & 23.303926 & 76.37 & 16.27 \\
$\mathrm{ZnS}$ & 0.9121 & 23.260166 & 74.84 & 15.88 \\
$\mathrm{In}_{2} \mathrm{~S}_{3}$ & 0.9198 & 23.153579 & 66.81 & 14.23 \\
\hline
\end{tabular}




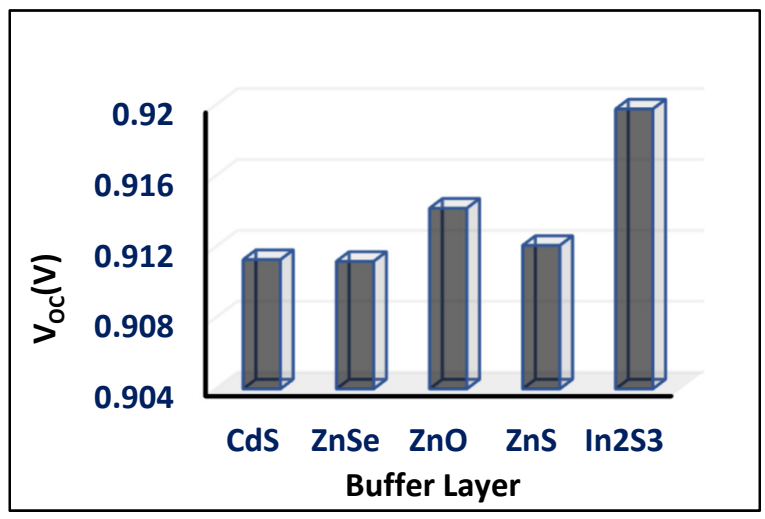

(a)

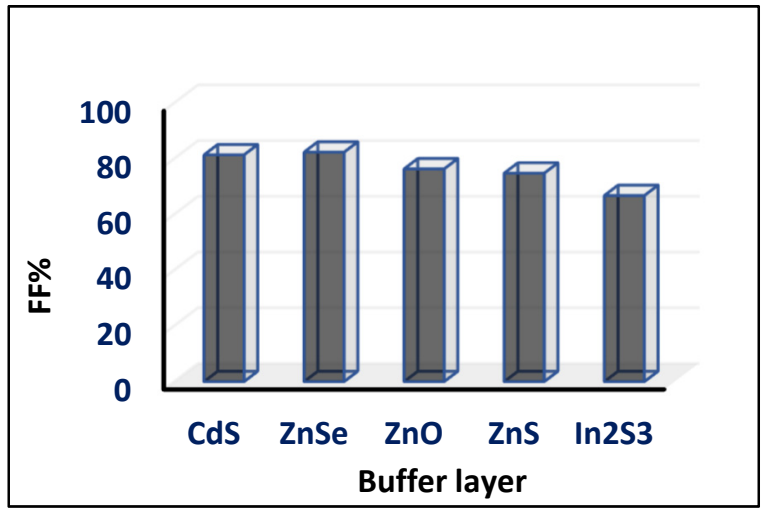

(c)

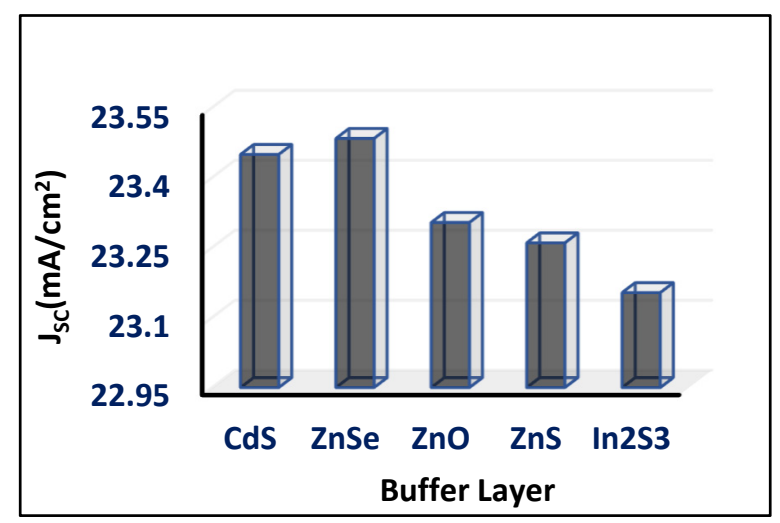

(b)

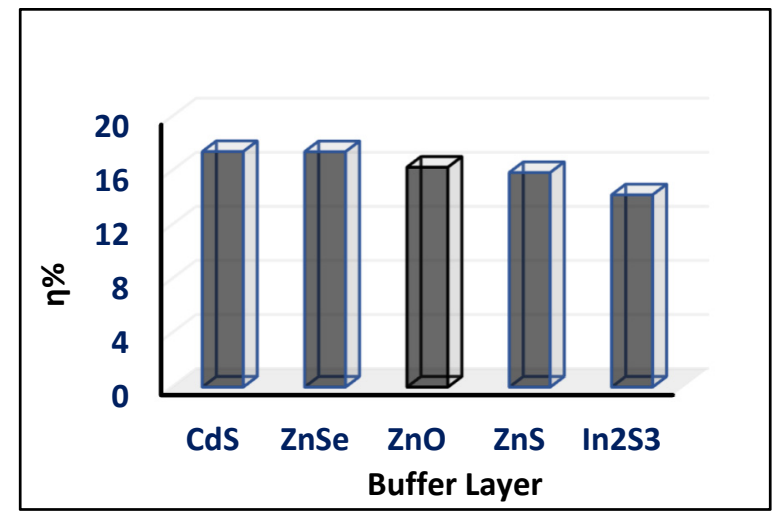

(d)

Figure 2. Effectiveness of the buffer material (donor) layer on photovoltaic parameters (a) $V_{\mathrm{OC}}(\mathbf{b}) J_{\mathrm{SC}}$ (c) $F F(\mathbf{d}) \eta$.
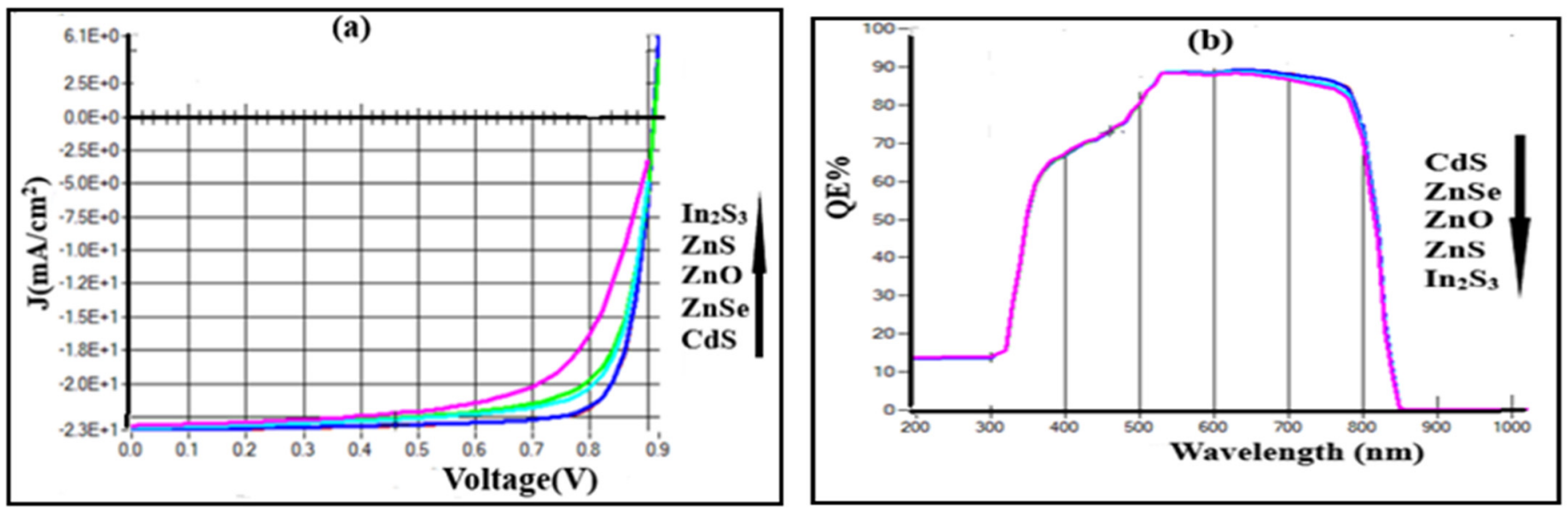

Figure 3. (a) $J-V$ current curves for the cell; (b) spectral response of solar cells and CdTe layer (acceptor characteristics) with different buffer layer at $\mathrm{T}=300 \mathrm{~K}$.

The following equation, Equation (5), can be used to calculate the spectrum response using the external quantum efficiency:

$$
E Q E(\lambda)=\frac{\frac{I(\lambda)}{q}}{\varphi_{p}(\lambda)}
$$

where $q$ represents the fundamental electrical charge, $I(\lambda)$ represents the photogenerated current and $\varphi_{p}(\lambda)$ represent the photon flux. On the light spectrum, Figure 4 depicts the external quantum efficiency $Q E(\%)$ for various buffer layers. The results reveal that when 
the buffer layer is CdS, the efficiency is at its peak [63]. The impact of the different buffers on the light spectrum might be seen in Figure $3 \mathrm{~b}$.

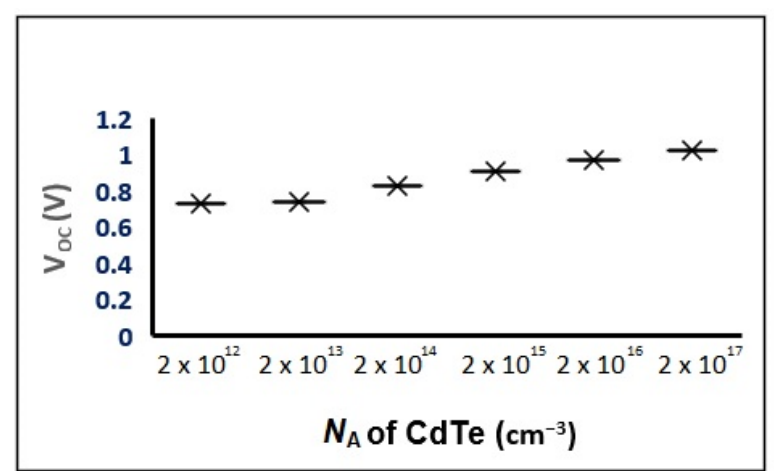

(a)

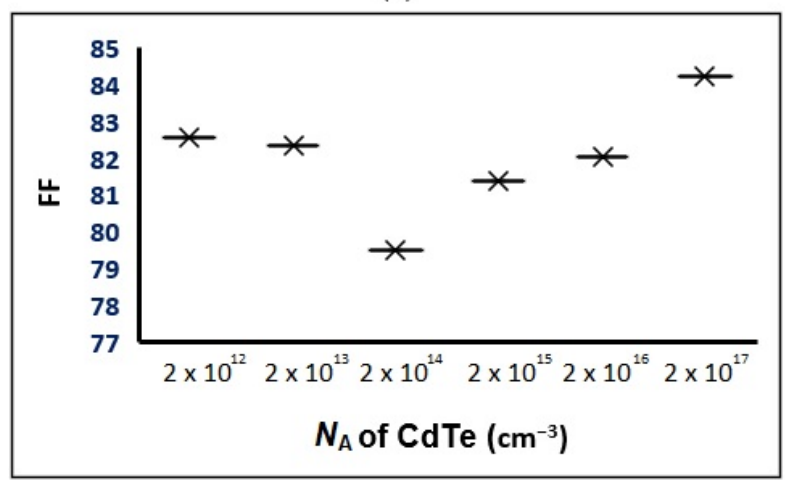

(c)

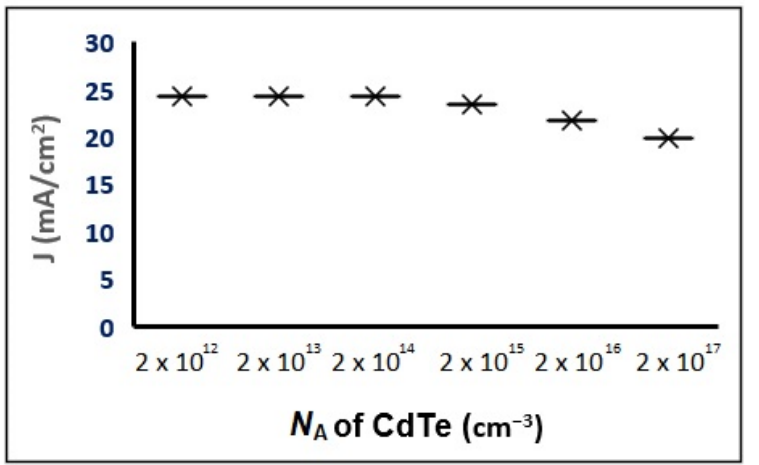

(b)

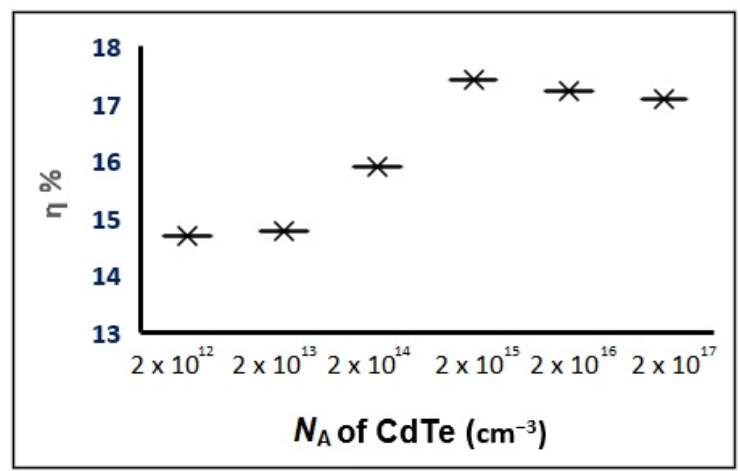

(d)

Figure 4. The simulated electrical performance parameters as a function of the acceptor charge carrier concentration $\left(N_{\mathrm{A}}\right)$ : (a) $V_{\mathrm{OC}},(\mathbf{b}) J_{\mathrm{SC}},(\mathbf{c}) F F,(\mathbf{d}) \eta \%$.

\subsection{Modelling and Optimization of CdTe Absorber Layer Doping Level}

The absorber $(\mathrm{CdTe})$ acceptor carrier concentration $\left(N_{\mathrm{A}}\right)$ changes in the ranges of $2 \times 10^{12} \mathrm{~cm}^{-3}$ to $2 \times 10^{17} \mathrm{~cm}^{-3}$, as shown in Table 5 . The main goal of this study is to obtain a carrier concentration $\left(N_{\mathrm{A}}\right)$ of the CdTe absorber layer without losses in cell performance. As consequence, low cost can be accomplished by reducing the amount of expensive materials that is used.

Table 5. Effectiveness of the acceptor carrier concentration $\left(N_{\mathrm{A}}\right)$ on the electrical cell performance parameters at $\mathrm{T}=300 \mathrm{~K}$.

\begin{tabular}{ccccc}
\hline$N_{\mathbf{A}}\left(\mathbf{c m}^{-3}\right)$ & $V_{\text {OC }}(\mathrm{V})$ & $J_{\text {SC }}\left(\mathbf{m A} / \mathbf{c m}^{2}\right)$ & $\boldsymbol{F F} \%$ & $\eta(\%)$ \\
\hline $2 \times 10^{12}$ & 0.7333 & 24.249669 & 82.57 & 14.68 \\
$2 \times 10^{13}$ & 0.7398 & 24.248777 & 82.33 & 14.77 \\
$2 \times 10^{14}$ & 0.8263 & 24.223452 & 79.49 & 15.91 \\
$2 \times 10^{15}$ & 0.9113 & 23.484037 & 81.38 & 17.42 \\
$2 \times 10^{16}$ & 0.9662 & 21.748835 & 82.02 & 17.23 \\
$2 \times 10^{17}$ & 1.0247 & 19.810091 & 84.21 & 17.09 \\
$2 \times 10^{12}$ & 0.7333 & 24.249669 & 82.57 & 14.68 \\
\hline
\end{tabular}

The electrical parameter performance with an acceptor (hole) carrier charge concentration $\left(N_{\mathrm{A}}\right)$ when the CdTe absorber has a $2000 \mathrm{~nm}$ thickness of is shown in Figure $4 \mathrm{a}-\mathrm{d}$. Figure 4 a depicts a linear rise in an open-circuit voltage $\left(V_{\mathrm{OC}}\right)$ with $\left(N_{\mathrm{A}}>2 \times 10^{14} \mathrm{~cm}^{-3}\right)$. Figure $4 \mathrm{~b}$ depicts a linear reduction in the short-circuit current density $\left(J_{S C}\right)$ with $\left(N_{\mathrm{A}}>2 \times 10^{14} \mathrm{~cm}^{-3}\right)$; this can be ascribed to an increase in free carrier charge recom- 
bination inside the bulk [64]. On the other hand, the fill factor $(F F)$, as shown in Figure 4c, increases linearly with $\left(N_{\mathrm{A}}>2 \times 10^{14} \mathrm{~cm}^{-3}\right)$. Figure $4 \mathrm{~d}$ also demonstrates that a low hole doping level $\left(N_{\mathrm{A}}<2 \times 10^{15} \mathrm{~cm}^{-3}\right)$ leads to a significant reduction in the device conversion efficiency, with values of less than $3 \%$. When the hole concentration of the absorber layer increases, however, minor cell efficiency changes are found, as shown by Equations (6)-(9):

$$
J_{S C}=q \sum T(\lambda) \frac{\varnothing_{i}\left(\lambda_{i}\right)}{h v_{i}} \eta\left(\lambda_{i}\right) \Delta \lambda_{i}
$$

where $q$ denotes the elementary charge, $\varnothing_{i}$ denotes the spectral power density, $T(\lambda)$ denotes the optical transmission and $\Delta \lambda_{i}$ denotes the distance between two adjacent wavelength values.

$$
\begin{gathered}
V_{O C}=\frac{n k T}{q} \ln \left(\frac{J_{S C}}{J_{O}}+1\right) \\
F F \%=\frac{V_{O C}-\ln \left(V_{O C}+0.72\right)}{V_{O C}+1} \\
\eta \%=\frac{V_{O C} \times J_{S C} \times F F \%}{P_{\text {in }}}
\end{gathered}
$$

The improved efficiency (Figure $4 \mathrm{~d}$ ) in the simulated findings is explained by the combined impact of current density $J_{\mathrm{SC}}$ saturation (Figure $4 \mathrm{~b}$ ) as well as the rapid increase of $V_{\mathrm{OC}}$ and $F F$ (Figure $4 \mathrm{a}$,c) with the acceptor carrier charge concentration $\left(N_{\mathrm{A}}\right)$. As a result, $\left(N_{\mathrm{A}} \sim 2 \times 10^{15} \mathrm{~cm}^{-3}\right)$ provides the best performance for the CdTe thin film.

The effect of the changes in the CdTe acceptor charge carrier concentration $\left(N_{\mathrm{A}}\right)$ on solar cell fundamental characteristics was thoroughly explored. The thin film's spectral response to the CdTe acceptor carrier charge concentration $\left(N_{\mathrm{A}}\right)$ is shown in Figure 5a. The simulated findings show that when the acceptor concentration increases from $2 \times 10^{12} \mathrm{~cm}^{-3}$ to $2 \times 10^{19} \mathrm{~cm}^{-3}$, the quantum efficiency $(Q E \%)$ decreases. The enhanced gathering of photons at longer wavelengths can be ascribed to this. The production of additional pairs of electron holes in the thin-film solar cell results from the absorption of longer wavelength photons, resulting in an increase in $J_{\mathrm{SC}}$ at low acceptor charge carrier concentrations $\left(\mathrm{N}_{\mathrm{A}}\right)$ (Figure $5 b$ ). The $J-V$ curves show that the $\mathrm{V}_{\mathrm{OC}}$ increases as the acceptor charge carrier concentration $\left(N_{\mathrm{A}}\right)$ of the CdTe layer increases $\left(N_{\mathrm{A}}>2 \times 10^{14} \mathrm{~cm}^{-3}\right)$. This rise shows that the open-circuit voltage $\left(\mathrm{V}_{\mathrm{OC}}\right)$ of the CdTe layer is substantially influenced by the acceptor charge carrier concentration $\left(N_{\mathrm{A}}\right)$. The generated electric field in the depletion region is altered when the acceptor (hole) carrier charge concentration $\left(N_{\mathrm{A}}\right)$ of the CdTe layer is high [65]. As a result, the free charge carrier recombination decreased, increasing the $V_{\text {OC. }}$. While lowering the CdTe acceptor carrier charge concentration below $2 \times 10^{15} \mathrm{~cm}^{-3}$ results in increased optical losses, which might be due to surface recombination at the back contact [66].

The following Equations (8) and (9) explain the $p-n$ junction model:

$$
\begin{gathered}
I_{O}=A q n_{i}^{2}\left(\frac{D_{e}}{L_{e} N_{A}}+\frac{D_{h}}{L_{h} N_{D}}\right) \\
V_{O C}=\frac{K T}{q \ln \left(I_{L} / I_{O}\right)}
\end{gathered}
$$

$I_{O}$ denotes the saturation current, $n_{i}$ is the intrinsic concentration, $A$ is the diode quality factor, $q$ is the elementary charge, $T$ is the temperature, $k$ is the Boltzmann constant, $I_{L}$ is the light-generated current, $L$ and $D$ are the diffusion length and coefficient and $N_{D}$ and $N_{A}$ are the donor and acceptor charge concentrations. The letters $h$ and $e$ stand for holes and electrons, respectively. As the acceptor carrier concentration $N_{\mathrm{A}}$ rises, the saturation current $I_{O}$ decreases, resulting in an increase in $V_{O C}$ and a drop in $J_{\mathrm{SC}}$. The reason for this is that when the acceptor carrier concentration is high, the recombination 
process increases and reduces the probability of electron-hole production pairs, lowering the $Q E(\%)$ of long wavelength photons. Long-wavelength photons will be absorbed profoundly in the absorber (CdTe) layer [67].
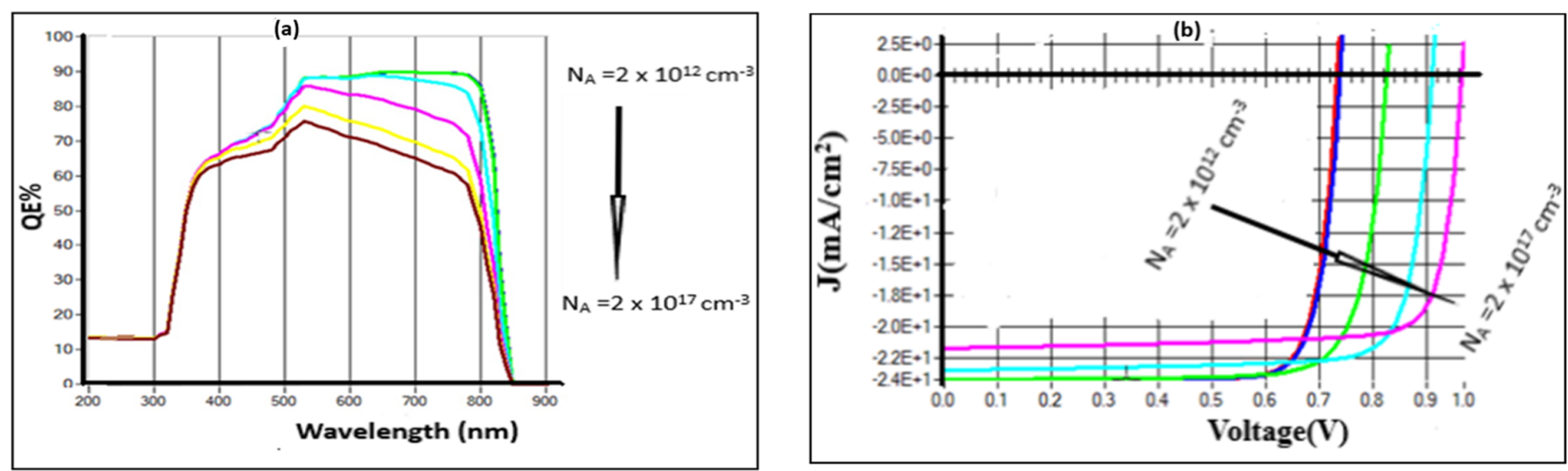

Figure 5. (a) Spectral response of the enhanced quantum efficiency $(Q E)$ at longer wavelength and (b) $J-V$ current curves for the cell with the increase of acceptor carrier concentration $\left(N_{\mathrm{A}}\right)$.

\subsection{Modelling and Optimization of ZnSe Buffer Layer Doping Level}

The major goal of this section is to decrease the buffer layer's losses (both optical and electrical). Following that, the carrier charge concentration level of the ZnSe layer was adjusted from $1 \times 10^{16} \mathrm{~cm}^{-3}$ to $1 \times 10^{22} \mathrm{~cm}^{-3}$. The effect of the ZnSe buffer on the thin-film performance characteristics is shown in Table 6 and Figure 6. With $\left(N_{\mathrm{D}}>1 \times 10^{18} \mathrm{~cm}^{-3}\right)$, the simulated results show that there is a small amount of modification that can be seen in the cell performance characteristics. The effectiveness of the thin film improved by $3 \%$ when the donor concentration increased to $\left(N_{\mathrm{D}}=1 \times 10^{22} \mathrm{~cm}^{-3}\right)$. It is better to have a high doping level in thin film to retain its exceptional overall performance [68]. The maximum conversion efficiency is $17.42 \%$ when the donor carrier charge concentration $\left(N_{\mathrm{D}} \sim 1 \times 10^{22} \mathrm{~cm}^{-3}\right)$ is used.

Figure 6a-d illustrate how a high donor concentration in the buffer layer improves cell performance. This is due to the apparent requirement for a minimum buffer layer thickness to compensate for the dislocation effect that is caused by the grid mismatches between the $\mathrm{ZnSe}$ and CdTe layers. Although the $J_{S C}, F F$ and $\eta$ parameters all rise (Figure $6 \mathrm{~b}-\mathrm{d}$ ), the $V_{O C}$ drops (Figure 6a). The explanation for this may be ascribed to photon loss on a large buffer layer, as seen in Figure 7a. As the concentration of the buffer layer $\left(N_{\mathrm{D}}\right)$ decreases, more incident photons that are generated by the ZnSe layer are absorbed, reducing the number of photons that the absorber (CdTe) layer can absorb. As illustrated in Figure $7 \mathrm{~b}$, absorbed photons generate fewer electron-hole pairs, resulting in a lower $Q E(\%)$. As the donor carrier charge concentrations increase, so does the $Q E$. In the simulation, it is better to have a high buffer layer donor concentration $\left(N_{\mathrm{D}}>1 \times 10^{18} \mathrm{~cm}^{-3}\right)$ for thin films.

Table 6. Effective of the donor charge carrier concentration $\left(N_{\mathrm{D}}\right)$ on the electrical cell performance parameters, at $\mathrm{T}=300 \mathrm{~K}$.

\begin{tabular}{ccccc}
\hline$N_{\mathbf{D}}\left(\mathbf{c m}^{-3}\right)$ & $V_{\text {OC }}(\mathbf{V})$ & $J_{\text {SC }}\left(\mathbf{m A} / \mathbf{c m}^{2}\right)$ & $F \boldsymbol{F}$ & $\eta(\%)$ \\
\hline $1 \times 10^{16}$ & 0.9178 & 23.275532 & 67.70 & 14.46 \\
$1 \times 10^{17}$ & 0.918 & 23.25272 & 68.22 & 14.57 \\
$1 \times 10^{18}$ & 0.9103 & 23.33507 & 78.62 & 16.70 \\
$1 \times 10^{19}$ & 0.9111 & 23.419193 & 80.54 & 17.19 \\
$1 \times 10^{20}$ & 0.9112 & 23.453013 & 81.07 & 17.33 \\
$1 \times 10^{21}$ & 0.9113 & 23.474864 & 81.29 & 17.39 \\
$1 \times 10^{22}$ & 0.9113 & 23.484037 & 81.38 & 17.42 \\
\hline
\end{tabular}




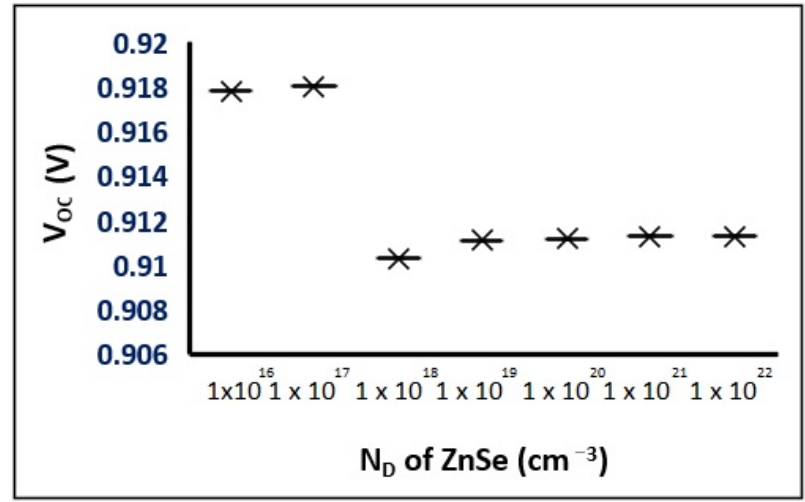

(a)

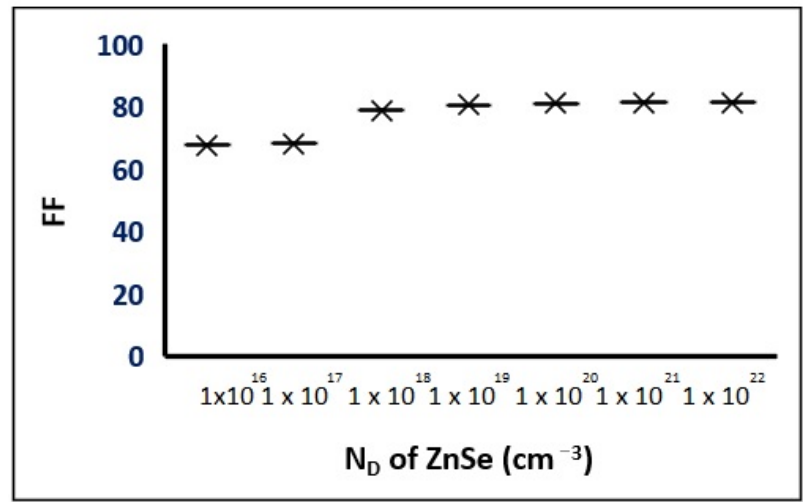

(c)

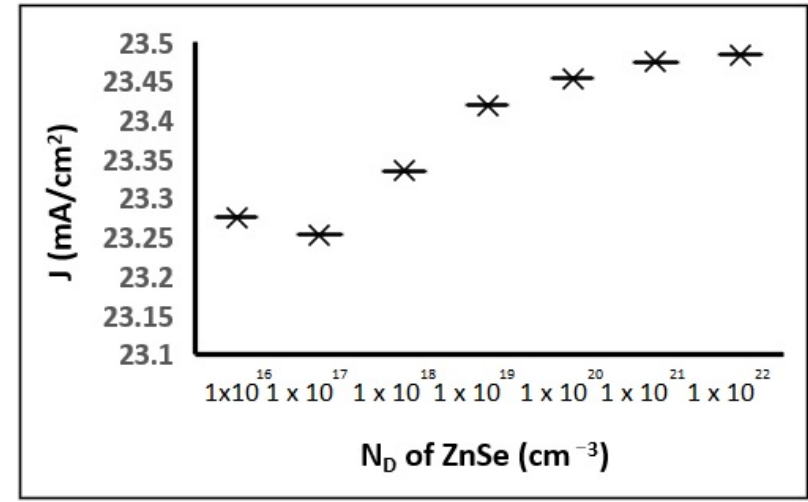

(b)

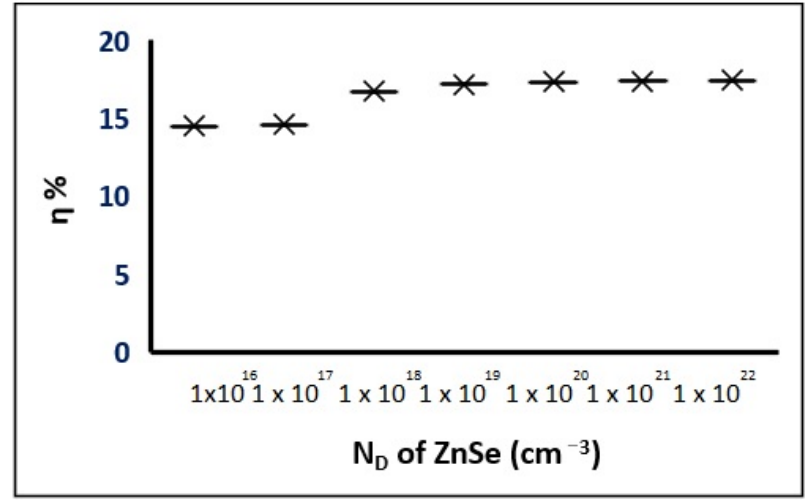

(d)

Figure 6. The simulated electrical performance parameters as a function of donor charge carrier concentration $\left(N_{\mathrm{D}}\right):\left(\right.$ a) $V_{\mathrm{OC}}$, (b) $J_{\mathrm{SC}},(\mathbf{c}) F F,(\mathbf{d}) \eta$.

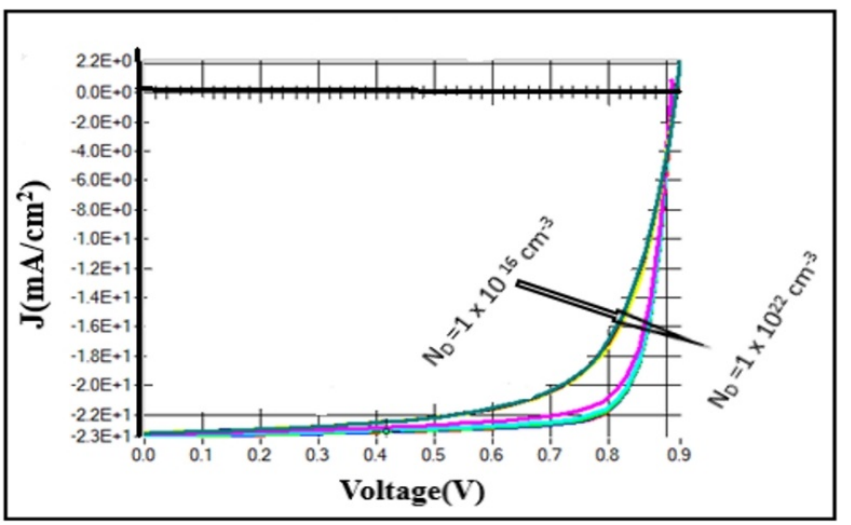

(a)

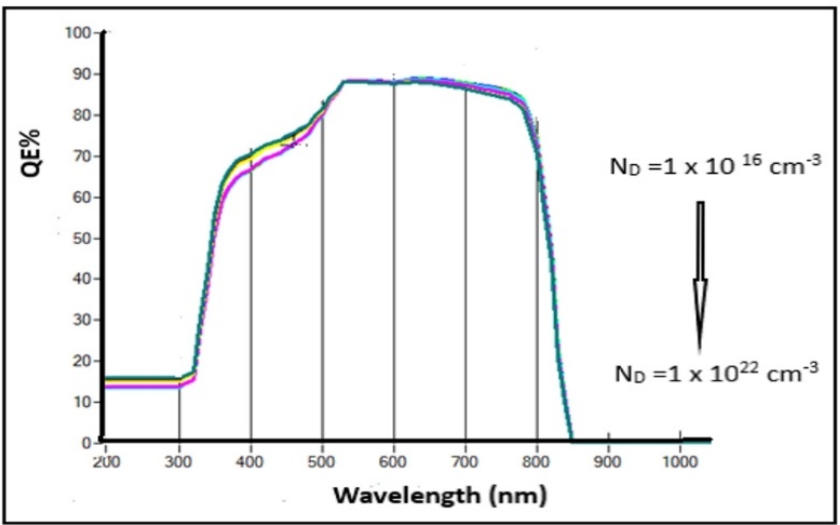

(b)

Figure 7. (a) $J-V$ as a function of $\mathrm{ZnSe}$ donner carrier concentration $\left(N_{\mathrm{D}}\right)$. (b) Spectral response of the enhanced quantum efficiency $(Q E)$ at longer wavelength with the increase in the donner carrier concentration $\left(N_{D}\right)$.

\subsection{Optimization of the Mo/CdTe/ZnSe/SnO $\mathrm{O}_{2}$ Thin Film-Based Solar Cell}

Based on the simulation results described above in the specified parameter range, the optimum PV characteristics can be achieved with an efficiency of $17.42 \%$ (with $V_{\mathrm{OC}}=0.9113 \mathrm{~V}$, $J_{\mathrm{SC}}=23.484037 \mathrm{~mA} / \mathrm{cm}^{2}$ and $F F=81.38$ ), when the thickness and acceptor concentration of the CdTe are $2000 \mathrm{~nm}$ and $2 \times 10^{15} \mathrm{~cm}^{-3}$, respectively, the thickness and donor concentration of the ZnSe are $25 \mathrm{~nm}$ and $1 \times 10^{22} \mathrm{~cm}^{-3}$ and the thickness and donor concentration of the $\mathrm{SnO}_{2}$ are $250 \mathrm{~nm}$ and $1 \times 10^{22} \mathrm{~cm}^{-3}$, respectively. Other electrical and optical parameters of the thin film are unchanged, as shown in Table 1. 


\subsubsection{Band Diagram}

One of the most notable factors impacting thin-film performance and current transmission across heterojunctions is band alignment shown in Figure 8. CdTe is used as the absorber layer ( 0 to $2 \mu \mathrm{m}$ ), where $\mathrm{ZnSe}$ is the buffer layer $\left(2 \mu \mathrm{m}\right.$ to $2.025 \mu \mathrm{m}$ ) and $\mathrm{SnO}_{2}$ is the window layer (from $2.025 \mu \mathrm{m}$ to $2.275 \mu \mathrm{m}$ ). When the absorber layer's conduction band is higher than the buffer layer's conduction band, the result is a "cliff" type band alignment [69]. As seen in Figure 8, this is the situation with CdTe thin films. It can be seen that the absorber, buffer and window layers have acceptable band alignment. Four recombination regions can be seen in the band diagram.

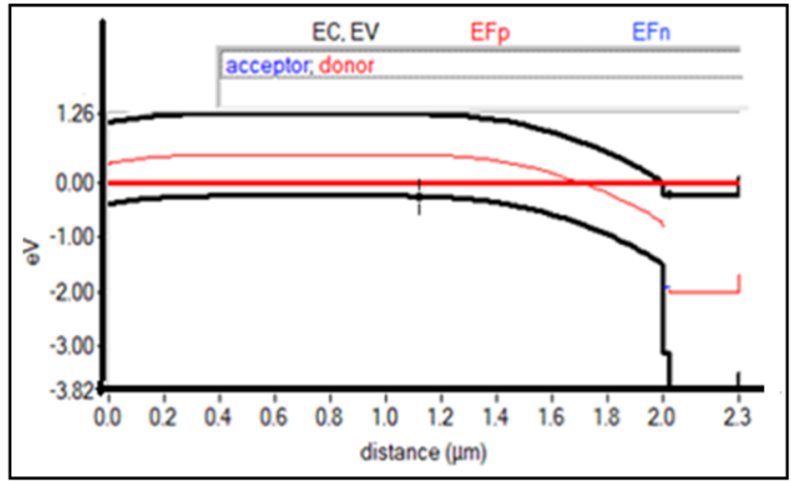

(a)

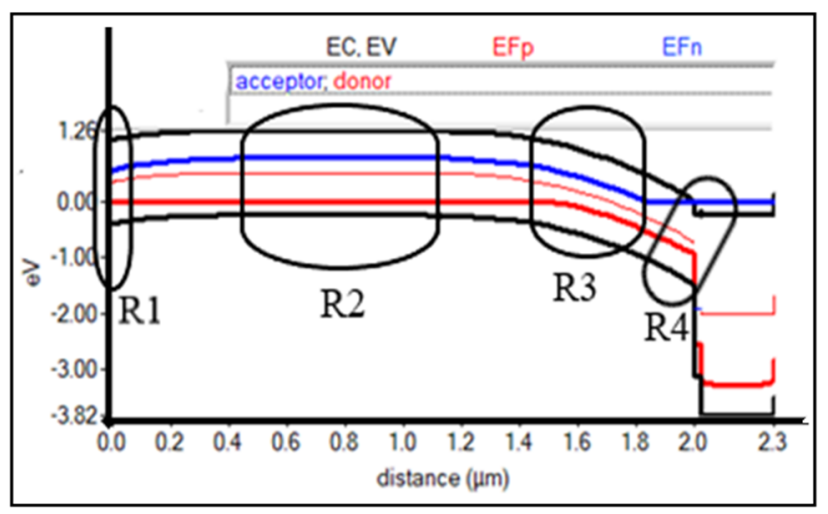

(b)

Figure 8. The band energy diagram CdTe layer (acceptor). ZnSe layer (buffer) and $\mathrm{SnO}_{2}$ layer window; (a) dark current, (b) photo current.

Recombination at the back contact (region R1), bulk (quasi-neutral) recombination in the absorber layer (region R2), space charge (region R3) and recombination at the absorber/buffer interface (region R4) are the four regions. The thin absorber layer will maintain the back contact close to the depletion region, resulting in a substantial increase in back contact recombination. Reasonable neutral interface defects for recombination were also included at the mid-gap to accommodate recombination at the $\mathrm{CdTe} / \mathrm{CdS}$ and $\mathrm{ZnSe} / \mathrm{SnO}_{2}$ interfaces [70]. The reflectance of the rear and front contact surfaces was adjusted to 0.1 and 0.9 , respectively (Table 3). Photons that traverse the absorber are reflected by this high reflectivity upon return contact, which improves absorption in the absorber.

\subsubsection{Current Mode}

The cross-over and roll-over of the $J-V$ curves are the $J-V$ characteristics of the $\mathrm{Mo} / \mathrm{CdTe} / \mathrm{ZnSe} / \mathrm{SnO}_{2}$ thin film. The intersection of dark and illuminated $J-V$ curves is known as a cross-over. The roll-over phenomenon occurs when the $J-V$ curve is meshed and when current levels of greater voltage are present. The dark and photo $J-V$ curves are depicted in Figure 9. The ideal layer carrier concentration densities in SCAPS-1D's computation $\left(\mathrm{CdTe} N_{\mathrm{A}}=2 \times 10^{15} \mathrm{~cm}^{-3}\right.$, ZnSe $N_{\mathrm{D}}=1 \times 10^{22} \mathrm{~cm}^{-3}$ and $\mathrm{SnO}_{2} N_{\mathrm{D}}=1 \times 10^{22} \mathrm{~cm}^{-3}$ ) were used in the simulation. Figure 9 shows the output cell efficiency parameters. The carrier concentration of the absorber layer/buffer layer interface recombination or the absorber/back contact was measured using this advantage [71].

\subsubsection{Quantum Efficiency}

The optimal $Q E$ for the thin film is shown in Figure 10. The ratio of the number of captured electrons to the number of incident photons on the solar cell is known as the $Q E$. The $Q E$ will be $100 \%$ when all the carriers have been gathered and when all the photons have been absorbed by CdTe. Photons $\left(h v \geq E_{g}\right)$ are absorbed by the absorber layer. Because the absorption layer cannot absorb low-energy photons, high-energy photons are able to contribute to the thermalization process, resulting in a variety of losses, such 
as shading losses, spectral mismatch losses, shading losses, incomplete absorption and collection losses, all of which reduce quantum efficiency [67].

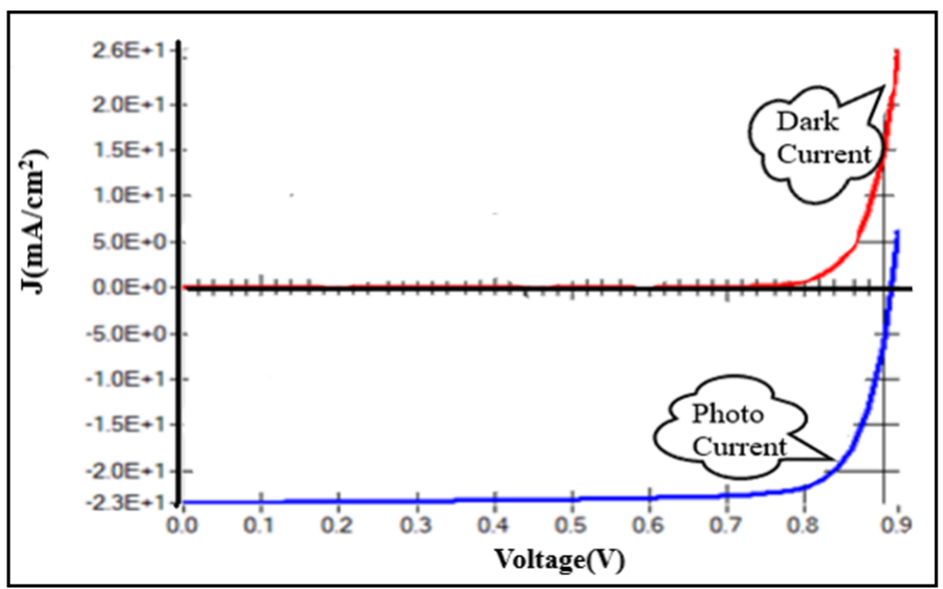

Figure 9. Current density with voltage, at $T=300 \mathrm{~K},\left(\mathrm{CdTe} N_{\mathrm{A}}=2 \times 10^{15} \mathrm{~cm}^{-3}, \mathrm{ZnSe}\right.$ $N_{\mathrm{D}}=1 \times 10^{22} \mathrm{~cm}^{-3}$ and $\mathrm{SnO}_{2} N_{\mathrm{D}}=1 \times 10^{22} \mathrm{~cm}^{-3}$ ).

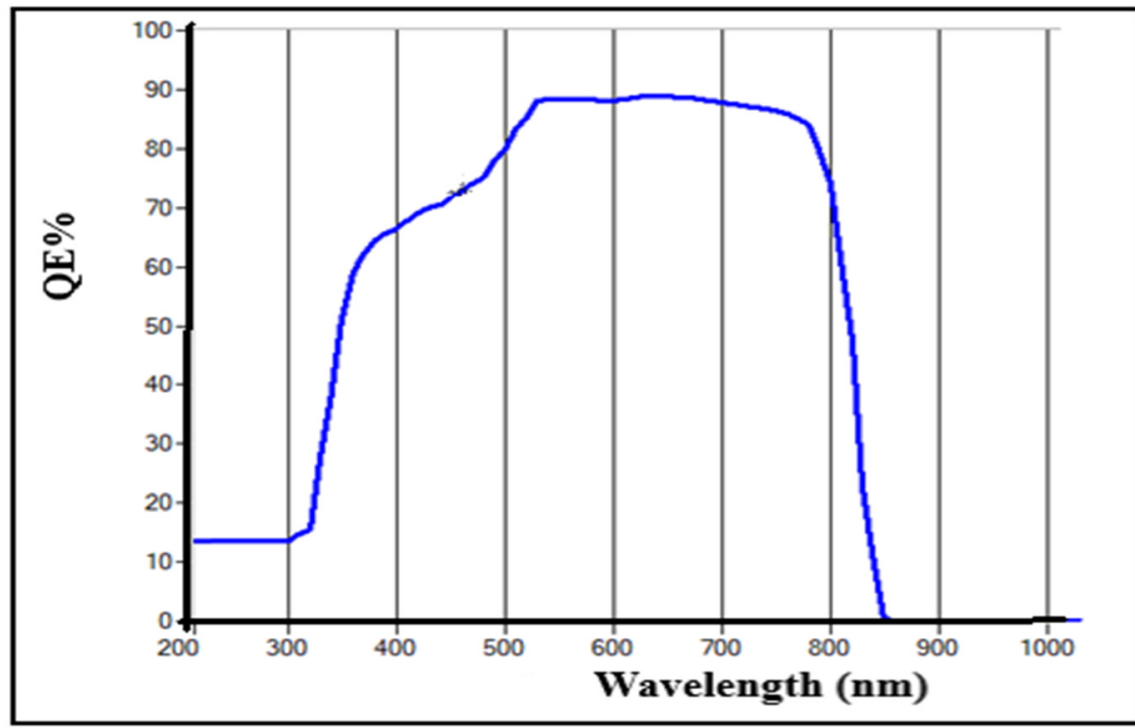

Figure 10. Quantum efficiency $(Q E, \%)$ outputs for the thin film (CdTe $N_{\mathrm{A}}=2 \times 10^{15} \mathrm{~cm}^{-3}$, ZnSe $N_{\mathrm{D}}=1 \times 10^{22} \mathrm{~cm}^{-3}$ and $\left.\mathrm{SnO}_{2} N_{\mathrm{D}}=1 \times 10^{22} \mathrm{~cm}^{-3}\right)$, at T $=300 \mathrm{~K}$.

\subsubsection{Effect of Transparent Conducting Layer (Window Layer)}

Both optical and electrical access are provided by transparent conducting oxide (TCO) layers. $\mathrm{SnO}_{2}$ was employed as the TCO in our situation. $\mathrm{SnO}_{2}$ has a bandgap of $3.6 \mathrm{eV}$, which is sufficient to cover the whole visible wavelength range. $\mathrm{SnO}_{2}$ has a thickness of $250 \mathrm{~nm}$ and a donor concentration of $1 \times 10^{22} \mathrm{~cm}^{-3}$, respectively. The window layer contributes to the production of electron-hole pairs slightly.

\subsection{Comparison between Recent Published Work and Proposed Work}

Table 7 shows that the proposed work outperforms recently published studies in terms of the open circuit voltage $\left(\mathrm{V}_{\mathrm{OC}}\right)$, shot circuit current $\left(J_{S C}\right)$ and conversion efficiency $(\eta, \%)$ of the cell construction. The proposed cell structure glass $/ \mathrm{Mo} / \mathrm{CdTe} / \mathrm{ZnSe} / \mathrm{SnO}_{2}$ outperforms other cell structures due to high $J_{S C}$ and $V_{O C}$, which result in higher conversion efficiency. The low $F F$ value might be related to defect states in any of the device's layers. If 
the proposed cell structure can be effectively manufactured, then this design method will become the superior option.

Table 7. Comparison of functional parameters with experimental results.

\begin{tabular}{|c|c|c|c|c|c|c|}
\hline & Buffer & $V_{\mathrm{OC}}(\mathrm{V})$ & $J_{\mathrm{SC}}\left(\mathrm{mA} / \mathrm{cm}^{2}\right)$ & $F F$ & $\eta(\%)$ & Ref. \\
\hline \multirow[t]{2}{*}{ CdS } & Experimental/CBD & 0.69 & 30.9 & 72 & 15.3 & [72] \\
\hline & Simulated/SCAPS-1D & 0.9113 & 23.4497335 & 81.41 & 17.43 & This work \\
\hline \multirow[t]{2}{*}{$\mathrm{ZnSe}$} & Experimental/CBD & 0.67 & 34.9 & 72.7 & 14.4 & [73] \\
\hline & Simulated/SCAPS-1D & 0.9112 & 23.484037 & 82.38 & 17.42 & This work \\
\hline \multirow[t]{2}{*}{$\mathrm{ZnS}$} & Experimental/CBD & 0.55 & 34.4 & 73 & 13.6 & [73] \\
\hline & Simulated/SCAPS-1D & 0.9121 & 23.260166 & 74.84 & .88 & This work \\
\hline \multirow[t]{2}{*}{$\mathrm{In}_{2} \mathrm{~S}_{3}$} & Experimental/ALCVD & 0.27 & 46.8 & 71.5 & 12.9 & [74] \\
\hline & Simulated/SCAPS-1D & 0.9198 & 23.153579 & 66.81 & 14.23 & This work \\
\hline \multirow[t]{2}{*}{$\mathrm{ZnO}$} & Experimental/CBD & 0.835 & 24.1 & 75.46 & 15.19 & [75] \\
\hline & Simulated/SCAPS-1D & 0.9142 & 23.303926 & 76.37 & 16.27 & This work \\
\hline
\end{tabular}

\section{Conclusions}

This article employs several buffer layers ( $\mathrm{CdS}, \mathrm{ZnSe}, \mathrm{ZnS}, \mathrm{In}_{2} \mathrm{~S}_{3}, \mathrm{ZnO}$ ) from a numerical simulation standpoint and the outcome indicates that $\mathrm{CdS}$ is the best buffer layer. Thus, it can be stated that $\mathrm{ZnSe}$ and $\mathrm{ZnO}$ are good options as alternate buffer layers for the CdS of CdTe solar cells, which was determined based on the findings from the simulation using SCAPS-1D. Additionally, the material that is used for the CdS buffer layer must be changed to a more appropriate material. Furthermore, numerical simulation analysis has shown that the rise in $N_{\mathrm{A}}$ and $N_{\mathrm{D}}$ results in an increase in solar cell performance. The effect on cell performance was also studied via the ZnSe buffer layer. Our analysis also showed that this effect can also be obtained at a value of $\eta \%$ of $17.42 \%$ (with $J_{\mathrm{SC}}=23.484037 \mathrm{~mA} / \mathrm{cm}^{2}, V_{\mathrm{OC}}=0.9113 \mathrm{~V}$ and $\left.F F=81.38\right)$ for a $2000 \mathrm{~nm}$ thick CdTe absorber layer with $N_{\mathrm{A}} \sim 2 \times 10^{15} \mathrm{~cm}^{-3}$, a $25 \mathrm{~nm}$ thick ZnSe buffer layer with $N_{\mathrm{D}} \sim 1 \times 10^{22} \mathrm{~cm}^{-3}$ and a $250 \mathrm{~nm}$ thick $\mathrm{SnO}_{2}$ window layer with $N_{\mathrm{D}} \sim 1 \times 10^{22} \mathrm{~cm}^{-3}$. While these results may enable us to create the requested CdTe thin-film solar cell, certain other effective factors have to be investigated in further studies that may influence cell performance.

Author Contributions: Data curation, S.H.Z.; formal analysis, S.H.Z. and A.H.Z.; investigation, S.H.Z.; methodology, S.H.Z. and A.H.Z.; project administration, S.H.Z.; resources, S.H.Z.; software, S.H.Z. and N.M.A.; validation, S.H.Z. and A.H.Z.; visualization, S.H.Z.; writing-original draft, S.H.Z.; writing-review \& editing, S.H.Z., A.H.Z., N.M.A. and A.F.I.A. All authors have read and agreed to the published version of the manuscript.

Funding: This research received no external funding.

Acknowledgments: The authors would like to acknowledge the University of Gent, Belgium, for providing the SCAPS simulator. Furthermore, we are grateful to Ajman University for supporting this study.

Conflicts of Interest: The authors declare that there are no conflicts of interest in this work.

\section{References}

1. Kruse, C.N.; Schäfer, S.; Haase, F.; Mertens, V.; Schulte-Huxel, H.; Lim, B.; Min, B.; Dullweber, T.; Peibst, R.; Brendel, R. Simulationbased roadmap for the integration of poly-silicon on oxide contacts into screen-printed crystalline silicon solar cells. Sci. Rep. 2021, 11, 996. [CrossRef]

2. Zhuk, S.; Kushwaha, A.; Wong, T.K.; Masudy-Panah, S.; Smirnov, A.; Dalapati, G.K. Critical review on sputter-deposited $\mathrm{Cu}_{2} \mathrm{ZnSnS}_{4}$ (CZTS) based thin film photovoltaic technology focusing on device architecture and absorber quality on the solar cells performance. Sol. Energy Mater. Sol. Cells 2017, 171, 239-252. [CrossRef]

3. Najm, A.S.; Ludin, N.A.; Abdullah, M.F.; Almessiere, M.A.; Ahmed, N.M.; Al-Alwani, M.A. Areca catechu extracted natural new sensitizer for dye-sensitized solar cell: Performance evaluation. J. Mater. Sci. Mater. Electron. 2020, 31, 3564-3575. [CrossRef]

4. Arce-Plaza, A.; Sánchez-Rodriguez, F.; Courel-Piedrahita, M.; Galán, O.V.; Hernandez-Calderon, V.; Ramirez-Velasco, S.; López, M.O. CdTe thin films: Deposition techniques and applications. Coat. Thin Film Technol. 2018, 131-148. [CrossRef] 
5. Gutierrez ZB, K.; Zayas-Bazán, P.G.; De Melo, O.; Moure-Flores, D.; Andraca-Adame, J.A.; Moreno-Ruiz, L.; Martínez-Gutiérrez, H.; Gallardo, S.; Sastré-Hernández, J.; Contreras-Puente, G. CdS/CdTe heterostructures for applications in ultra-thin solar cells. Materials 2018, 11, 1788. [CrossRef] [PubMed]

6. Maxwell, G.L. Characterization and Modeling of $\mathrm{CdCl}_{2}$ Treated CdTe/CdS Thin-Film Solar Cells; Colorado State University Libraries, Colorado State University: Colorado, CO, USA, 2010.

7. Kwon, D. Studies of Sputtered Cadmium Telluride and Cadmium Selenide Solar Cells; The University of Toledo: Toledo, OH, USA, 2012.

8. Hsiao, K.-J. Electron-Reflector Strategy for CdTe Thin-Film Solar Cells. Ph.D. Thesis, Colorado State University, Colorado, CO, USA, 2010.

9. Emery, K.; Hishikawa, Y.; Warta, W.; Dunlop, E.; Levi, D.; Ho-Baillie, A. Solar cell efficiency tables (Version 46). Mat. Res. Soc. 2015, 23, 231-234.

10. Bouroushian, M. Electrochemistry of the Chalcogens. In Electrochemistry of Metal Chalcogenides; Springer: Berlin/Heidelberg, Germany, 2010; pp. 57-75.

11. Belmonte, R.; Angel, M. Quo Vadis Solar Energy Research? Appl. Sci. 2021, 11, 3015. [CrossRef]

12. Bouloufa, A.; Djessas, K.; Zegadi, A. Numerical simulation of CuInxGa $1-x \mathrm{Xe}_{2}$ solar cells by AMPS-1D. Thin Solid Film. 2007, 515, 6285-6287. [CrossRef]

13. Guo, Y.; Deng, X. Electrodeposition of CdTe thin films and their photoelectrochemical behaviour. Sol. Energy Mater. Sol. Cells 1993, 29, 115-122. [CrossRef]

14. Su, J.; Minegishi, T.; Katayama, M.; Domen, K. Photoelectrochemical hydrogen evolution from water on a surface modified CdTe thin film electrode under simulated sunlight. J. Mater. Chem. A 2017, 5, 4486-4492. [CrossRef]

15. Echendu, O.; Okeoma, K.; Oriaku, C.; Dharmadasa, I. Electrochemical deposition of CdTe semiconductor thin films for solar cell application using two-electrode and three-electrode configurations: A comparative study. Adv. Mater. Sci. Eng. 2016, 2016. [CrossRef]

16. Nikale, V.; Shinde, S.; Bhosale, C.; Rajpure, K. Physical properties of spray deposited CdTe thin films: PEC performance. J. Semicond. 2011, 32, 033001. [CrossRef]

17. Abdul-Manaf, N.A.; Salim, H.I.; Madugu, M.L.; Olusola, O.I.; Dharmadasa, I.M. Electro-plating and characterisation of CdTe thin films using $\mathrm{CdCl}_{2}$ as the cadmium source. Energies 2015, 8, 10883-10903. [CrossRef]

18. Salim, H.; Patel, V.; Abbas, A.; Walls, J.; Dharmadasa, I. Electrodeposition of CdTe thin films using nitrate precursor for applications in solar cells. J. Mater. Sci. Mater. Electron. 2015, 26, 3119-3128. [CrossRef]

19. Ojo, A.; Dharmadasa, I. Analysis of electrodeposited CdTe thin films grown using cadmium chloride precursor for applications in solar cells. J. Mater. Sci. Mater. Electron. 2017, 28, 14110-14120. [CrossRef]

20. Kwon, Y.; Seo, J.; Kang, Y.; Kim, D.; Kim, J. Bifacial CdS/CdTe thin-film solar cells using a transparent silver nanowire/indium tin oxide back contact. Opt. Express 2018, 26, A30-A38. [CrossRef]

21. Holi, A.M.; Al-Zahrani, A.A.; Najm, A.S.; Chelvanathan, P.; Amin, N. PbS/CdS/ZnO nanowire arrays: Synthesis, structural, optical, electrical and photoelectrochemical properties. Chem. Phys. Lett. 2020, 750, 137486. [CrossRef]

22. Najm, A.S.; Chelvanathan, P.; Tiong, S.K.; Ferdaous, M.T.; Shahahmadi, S.A.; Yusoff, Y.; Sopian, K.; Amin, N. Numerical Insights into the Influence of Electrical Properties of n-CdS Buffer Layer on the Performance of SLG/Mo/p-Absorber/n-CdS/n-ZnO/Ag Configured Thin Film Photovoltaic Devices. Coatings 2021, 11, 52. [CrossRef]

23. Voznyi, A.; Kosyak, V.; Opanasyuk, A.; Tirkusova, N.; Grase, L.; Medvids, A.; Mezinskis, G. Structural and electrical properties of SnS2 thin films. Mater. Chem. Phys. 2016, 173, 52-61. [CrossRef]

24. Zheng, X.; Li, W.; Aberle, A.G.; Venkataraj, S. Efficiency enhancement of ultra-thin Cu (In, Ga) Se 2 solar cells: Optimizing the absorber bandgap profile by numerical device simulations. Curr. Appl. Phys. 2016, 16, 1334-1341. [CrossRef]

25. Chelvanathan, P.; Yusoff, Y.; Haque, F.; Akhtaruzzaman, M.; Alam, M.; Alothman, Z.; Rashid, M.; Sopian, K.; Amin, N. Growth and characterization of RF-sputtered $\mathrm{ZnS}$ thin film deposited at various substrate temperatures for photovoltaic application. Appl. Surf. Sci. 2015, 334, 138-144. [CrossRef]

26. Ho, W.-H.; Hsu, C.-H.; Yeh, T.-H.; Chang, Y.-H.; Wei, S.-Y.; Lin, T.-Y.; Lai, C.-H. Room-temperature chemical solution treatment for flexible $\mathrm{ZnS}(\mathrm{O}, \mathrm{OH}) / \mathrm{Cu}(\mathrm{In}, \mathrm{Ga}) \mathrm{Se}_{2}$ solar cell: Improvements in interface properties and metastability. ACS Appl. Mater. Interfaces 2016, 8, 6709-6717. [CrossRef] [PubMed]

27. Abd El Halim, B.; Mahfoud, A.; Elamine, D.M. Numerical analysis of potential buffer layer for $\mathrm{Cu}_{2} \mathrm{ZnSnS}_{4}(\mathrm{CZTS})$ solar cells. Optik 2020, 204, 164155. [CrossRef]

28. Slonopas, A.; Ryan, H.; Foley, B.; Sun, Z.; Sun, K.; Globus, T.; Norris, P. Growth mechanisms and their effects on the opto-electrical properties of CdS thin films prepared by chemical bath deposition. Mater. Sci. Semicond. Process. 2016, 52, 24-31. [CrossRef]

29. Han, J.; Spanheimer, C.; Haindl, G.; Fu, G.; Krishnakumar, V.; Schaffner, J.; Fan, C.; Zhao, K.; Klein, A.; Jaegermann, W. Optimized chemical bath deposited CdS layers for the improvement of CdTe solar cells. Sol. Energy Mater. Sol. Cells 2011, 95, 816-820. [CrossRef]

30. Dharmadasa, R.; Lavery, B.; Dharmadasa, I.; Druffel, T. Intense pulsed light treatment of cadmium telluride nanoparticle-based thin films. ACS Appl. Mater. Interfaces 2014, 6, 5034-5040. [CrossRef] [PubMed]

31. Cai, W.; Feng, L.; Cai, Y.; Zhang, J.; Li, B.; Li, W.; Wu, L.; Lei, Z.; Zheng, J. Produce technology of CdTe thin film modules and design of manufacture line. In Proceedings of the 2006 IEEE 4th World Conference on Photovoltaic Energy Conference, Waikoloa, HI, USA, 7-12 May 2006; pp. 585-587. 
32. Okamoto, T.; Shiina, Y.; Okamoto, S. Investigation of Cu-doping effects in CdTe solar cells by junction photoluminescence with various excitation wavelengths. Jpn. J. Appl. Phys. 2017, 56, 08MC02. [CrossRef]

33. Okamoto, T.; Hayashi, R.; Ogawa, Y.; Hosono, A.; Doi, M. Fabrication of polycrystalline CdTe thin-film solar cells using carbon electrodes with carbon nanotubes. Jpn. J. Appl. Phys. 2015, 54, 04DR01. [CrossRef]

34. Jamil, N.Y.; Ivashchenko, M.; Abdulla, S.; Muhammed, A.; Pogrebnjak, A. Design and Fabrication Heterojunction Solarcell of Si-CdS-ZnO Thin Film. In Proceedings of the International Conference Nanomaterials: Applications and Properties; Sumy State University Publishing: Washington, DC, USA, 2012; p. 04NMEEE09.

35. Zyoud, S.; Zyoud, A. Effect of Absorber (Acceptor) and Buffer (Donor) Layers Thickness on Mo/CdTe/CdS/ITO Thin Film Solar Cell Performance: SCAPS-1D Simulation Aspect. Int. Rev. Model. Simul. (IREMOS) 2021, 14, 10-17. [CrossRef]

36. Naghavi, N.; Chassaing, E.; Bouttemy, M.; Rocha, G.; Renou, G.; Leite, E.; Etcheberry, A.; Lincot, D. Electrodeposition of $\operatorname{In}_{2} \mathrm{~S}_{3}$ buffer layer for Cu (In, Ga) Se 2 solar cells. Energy Procedia 2011, 10, 155-160. [CrossRef]

37. Adam, K.B.; Miyauchi, H. Optimization of a Photovoltaic Hybrid Energy Storage System Using Energy Storage Peak Shaving. Int. Rev. Electr. Eng. 2019, 14, 8-18. [CrossRef]

38. Piarah, W.; Djafar, Z. A New Simulation of Photovoltaic and Thermoelectric Generator Hybrid System with a Beam Splitter Cold and Hot Mirror for Low Intensity. Int. Rev. Mech. Eng. 2019, 13, 559-567. [CrossRef]

39. Dib, K.; Chenni, R. A Combined MPPT Algorithm for Photovoltaic Systems Based Arduino Microcontroller. Changes 2018, 11, 12. [CrossRef]

40. Burgelman, M.; Nollet, P.; Degrave, S. Modelling polycrystalline semiconductor solar cells. Thin Solid Film. 2000, 361, 527-532. [CrossRef]

41. Decock, K.; Khelifi, S.; Burgelman, M. Modelling multivalent defects in thin film solar cells. Thin Solid Film. 2011, 519, 7481-7484. [CrossRef]

42. Burgelman, M.; Verschraegen, J.; Degrave, S.; Nollet, P. Modeling thin-film PV devices. Prog. Photovolt. Res. Appl. 2004, 12, 143-153. [CrossRef]

43. Movla, H. Optimization of the CIGS based thin film solar cells: Numerical simulation and analysis. Optik 2014, 125, 67-70. [CrossRef]

44. Amin, N.; Matin, M.; Aliyu, M.; Alghoul, M.; Karim, M.; Sopian, K. Prospects of back surface field effect in ultra-thin highefficiency CdS/CdTe solar cells from numerical modeling. Int. J. Photoenergy 2010, 1-8. [CrossRef]

45. Amin, N.; Yamada, A.; Konagai, M. Effect of ZnTe and CdZnTe Alloys at the Back Contact of 1- $\mu$ m-Thick CdTe Thin Film Solar Cells. Jpn. J. Appl. Phys. 2002, 41, 2834. [CrossRef]

46. Aramoto, T.; Kumazawa, S.; Higuchi, H.; Arita, T.; Shibutani, S.; Nishio, T.; Nakajima, J.; Tsuji, M.; Hanafusa, A.; Hibino, T. 16.0\% efficient thin-film CdS/CdTe solar cells. Jpn. J. Appl. Phys. 1997, 36, 6304. [CrossRef]

47. Asaduzzaman, M.; Bahar, A.N.; Bhuiyan, M.M.R. Dataset demonstrating the modeling of a high performance Cu (In, Ga) Se 2 absorber based thin film photovoltaic cell. Data Brief 2017, 11, 296. [CrossRef] [PubMed]

48. Asaduzzaman, M.; Bahar, A.N.; Masum, M.M.; Hasan, M.M. Cadmium free high efficiency Cu $\mathrm{ZnSn}_{2}(\mathrm{~S}, \mathrm{Se})_{4}$ solar cell with $\mathrm{Zn}_{1}-\mathrm{xSn}_{\mathrm{x}} \mathrm{O}_{\mathrm{y}}$ buffer layer. Alex. Eng. J. 2017, 56, 225-229. [CrossRef]

49. Asaduzzaman, M.; Hasan, M.; Bahar, A.N. An investigation into the effects of band gap and doping concentration on Cu (In, Ga) $\mathrm{Se}_{2}$ solar cell efficiency. SpringerPlus 2016, 5, 578. [CrossRef] [PubMed]

50. Asaduzzaman, M.; Hosen, M.; Ali, M.; Bahar, A.N. Non-toxic buffer layers in flexible Cu (In, Ga) Se 2 photovoltaic cell applications with optimized absorber thickness. Int. J. Photoenergy 2017, 1-8. [CrossRef]

51. Gessert, T.; Sheldon, P.; Li, X.; Dunlavy, D.; Niles, D.; Sasala, R.; Albright, S.; Zadler, B. Studies of ZnTe back contacts to CdS/CdTe solar cells. In Proceedings of the Conference Record of the Twenty Sixth IEEE Photovoltaic Specialists Conference, Anaheim, CA, USA, 29 September-3 October 1997; pp. 419-422.

52. Hossain, S.; Amin, N.; Martin, M.; Aliyu, M.M.; Razykov, T.; Sopian, K. A numerical study on the prospects of high efficiency ultra thin $\mathrm{Zn}_{\mathrm{x}} \mathrm{Cd}_{1-\mathrm{x}} \mathrm{S} / \mathrm{CdTe}$ Solar Cell. Chalcogenide Lett. 2011, 8, 263-272.

53. Lee, Y.-J.; Gray, J.L. Numerical modeling of polycrystalline CdTe and CIS solar cells. In Proceedings of the Conference Record of the Twenty Third IEEE Photovoltaic Specialists Conference-1993 (Cat. No. 93CH3283-9), Louisville, KY, USA, 10-14 May 1993; pp. 586-591.

54. Mahabaduge, H.; Rance, W.; Burst, J.; Reese, M.; Meysing, D.; Wolden, C.; Li, J.; Beach, J.; Gessert, T.; Metzger, W. High-efficiency, flexible CdTe solar cells on ultra-thin glass substrates. Appl. Phys. Lett. 2015, 106, 133501. [CrossRef]

55. Mirkamali, A.S.; Muminov, K.K. Simulation of the efficiency of CdS/CdTe tandem multi-junction solar cells. arXiv 2016, arXiv:1602.01583.

56. Kotipalli, R.; Poncelet, O.; Li, G.; Zeng, Y.; Francis, L.; Vermang, B.; Flandre, D. Addressing the impact of rear surface passivation mechanisms on ultra-thin $\mathrm{Cu}$ (In, Ga) Se 2 solar cell performances using SCAPS 1-D model. Sol. Energy 2017, 157, 603-613. [CrossRef]

57. Limam, N.; Belghachi, A. Analysis of CIGS and CdTe solar cell concentrators. J. Ovonic. Res. Vol. 2017, 13, 129-134.

58. Jhuma, F.A.; Shaily, M.Z.; Rashid, M.J. Towards high-efficiency CZTS solar cell through buffer layer optimization. Mater. Renew. Sustain. Energy 2019, 8, 6. [CrossRef]

59. Cozza, D.; Ruiz, C.M.; Duché, D.; Simon, J.J.; Escoubas, L. Modeling the back contact of $\mathrm{Cu}_{2} \mathrm{ZnSnSe}_{4}$ solar cells. IEEE J. Photovolt. 2016, 6, 1292-1297. [CrossRef] 
60. Avellaneda, D.; Nair, M.; Nair, P. $\mathrm{Cu}_{2} \mathrm{SnS}_{3}$ and $\mathrm{Cu}_{4} \mathrm{SnS}_{4}$ thin films via chemical deposition for photovoltaic application. J. Electrochem. Soc. 2010, 157, D346. [CrossRef]

61. Minbashi, M.; Ghobadi, A.; Ehsani, M.; Dizaji, H.R.; Memarian, N. Simulation of high efficiency SnS-based solar cells with SCAPS. Solar Energy 2018, 176, 520-525. [CrossRef]

62. Zyoud, S.H.; Zyoud, A.H.; Abdelkader, A.; Ahmed, N.M. Numerical Simulation for Optimization of ZnTe-Based Thin-Film Heterojunction Solar Cells with Different Metal Chalcogenide Buffer Layers Replacements: SCAPS-1D Simulation Program. Int. Rev. Model. Simul. 2021, 14. [CrossRef]

63. Enam, F.; Rahman, K.; Kamaruzzaman, M.; Sobayel, K.; Chelvanathan, P.; Bais, B.; Akhtaruzzaman, M.; Alamoud, A.; Amin, N. Design prospects of cadmium telluride/silicon (CdTe/Si) tandem solar cells from numerical simulation. Optik 2017, 139, 397-406. [CrossRef]

64. Kartopu, G.; Oklobia, O.; Turkay, D.; Diercks, D.; Gorman, B.; Barrioz, V.; Campbell, S.; Major, J.; Al Turkestani, M.; Yerci, S. Study of thin film poly-crystalline CdTe solar cells presenting high acceptor concentrations achieved by in-situ arsenic doping. Sol. Energy Mater. Sol. Cells 2019, 194, 259-267. [CrossRef]

65. Ablekim, T.; Swain, S.K.; Yin, W.-J.; Zaunbrecher, K.; Burst, J.; Barnes, T.M.; Kuciauskas, D.; Wei, S.-H.; Lynn, K.G. Selfcompensation in arsenic doping of CdTe. Sci. Rep. 2017, 7, 4563. [CrossRef] [PubMed]

66. Grover, S.; Li, X.; Zhang, W.; Yu, M.; Xiong, G.; Gloeckler, M.; Malik, R. Characterization of arsenic doped CdTe layers and solar cells. In Proceedings of the 2017 IEEE 44th Photovoltaic Specialist Conference (PVSC), Washington, DC, USA, 25-30 June 2017; pp. 1193-1195.

67. Kanevce, A.; Reese, M.O.; Barnes, T.; Jensen, S.; Metzger, W. The roles of carrier concentration and interface, bulk and grainboundary recombination for $25 \%$ efficient CdTe solar cells. J. Appl. Phys. 2017, 121, 214506. [CrossRef]

68. Bailie, C.D.; Christoforo, M.G.; Mailoa, J.P.; Bowring, A.R.; Unger, E.L.; Nguyen, W.H.; Burschka, J.; Pellet, N.; Lee, J.Z.; Grätzel M. Semi-transparent perovskite solar cells for tandems with silicon and CIGS. Energy Environ. Sci. 2015, 8, 956-963. [CrossRef]

69. Wang, K.; Gunawan, O.; Todorov, T.; Shin, B.; Chey, S.; Bojarczuk, N.; Mitzi, D.; Guha, S. Thermally evaporated Cu 2 ZnSnS $_{4}$ solar cells. Appl. Phys. Lett. 2010, 97, 143508. [CrossRef]

70. Zhao, W.; Zhou, W.; Miao, X. Numerical simulation of CZTS thin film solar cell. In Proceedings of the 2012 7th IEEE International Conference on Nano/Micro Engineered and Molecular Systems (NEMS), Kyoto, Japan, 5-8 March 2012; pp. 502-505.

71. Niemegeers, A.; Burgelman, M. Effects of the Au/CdTe back contact on IV and CV characteristics of Au/CdTe/CdS/TCO solar cells. J. Appl. Phys. 1997, 81, 2881-2886. [CrossRef]

72. Islam, M.M.; Ishizuka, S.; Yamada, A.; Sakurai, K.; Niki, S.; Sakurai, T.; Akimoto, K. CIGS solar cell with MBE-grown ZnS buffer layer. Sol. Energy Mater. Sol. Cells 2009, 93, 970-972. [CrossRef]

73. Ennaoui, A.; Eisele, W.; Lux-Steiner, M.; Niesen, T.; Karg, F. Highly efficient Cu (Ga, In)(S, Se) 2 thin film solar cells with zinc-compound buffer layers. Thin Solid Film 2003, 431, 335-339. [CrossRef]

74. Spiering, S.; Eicke, A.; Hariskos, D.; Powalla, M.; Naghavi, N.; Lincot, D. Large-area Cd-free CIGS solar modules with In $2 \mathrm{~S}_{3}$ buffer layer deposited by ALCVD. Thin Solid Film 2004, 451, 562-566. [CrossRef]

75. Kartopu, G.; Williams, B.L.; Zardetto, V.; Gürlek, A.K.; Clayton, A.J.; Jones, S.; Kessels, W.M.; Creatore, M.; Irvine, S.J. Enhancement of the photocurrent and efficiency of CdTe solar cells suppressing the front contact reflection using a highly-resistive ZnO buffer layer. Sol. Energy Mater. Sol. Cells 2019, 191, 78-82. [CrossRef] 